\title{
Correction: Medical research and audit skills training for undergraduates: an international analysis and student-focused needs assessment
}

STARSurg Collaborative. Medical research and audit skills training for undergraduates: an international analysis and student-focused needs assessment. Postgrad Med J 2018;94:37-42.

The following authors are to be considered joint first authors for this article: Michael Bath, Henry A Claireaux, Thomas M Drake, Midhun Mohan.

(c) Article author(s) (or their employer(s) unless otherwise stated in the text of the article) 2018. All rights reserved. No commercial use is permitted unless otherwise expressly granted.

Postgrad Med J 2018;94:324. doi:10.1136/postgradmedj-2017-135035corr2.

D) Check for updates 